\title{
Corporate Social Responsibility, Audit Committee Expertise, and Financial Reporting: Empirical Evidence from Korea
}

\author{
Haeyoung Ryu ${ }^{1}$, Soo-Joon Chae ${ }^{2}$ and Bomi Song ${ }^{3, *}$ \\ 1 Department of Business Administration, Hansei University, Gunpo-si 15852, Korea; hyryu@hansei.ac.kr \\ 2 Department of Business Administration \& Accounting, Kangwon National University, Chuncheon-si 24341, \\ Korea; sjchae@kangwon.ac.kr \\ 3 College of Business, Gachon University, Seongnam-si 13120, Korea \\ * Correspondence: springsbm@gachon.ac.kr
}

check for updates

Citation: Ryu, H.; Chae, S.-J.; Song, B. Corporate Social Responsibility, Audit Committee Expertise, and Financial Reporting: Empirical Evidence from Korea. Sustainability 2021, 13, 10517. https://doi.org/ $10.3390 /$ su131910517

Academic Editor: Ioannis Nikolaou

Received: 27 August 2021

Accepted: 19 September 2021

Published: 22 September 2021

Publisher's Note: MDPI stays neutral with regard to jurisdictional claims in published maps and institutional affiliations.

Copyright: (C) 2021 by the authors. Licensee MDPI, Basel, Switzerland. This article is an open access article distributed under the terms and conditions of the Creative Commons Attribution (CC BY) license (https:/ / creativecommons.org/licenses/by/ $4.0 /)$.

\begin{abstract}
Corporate social responsibility (CSR) involves multiple activities and is influenced by the cultural and legal environment of the country in which a firm is located. This study examines the role of audit committees' (AC) financial expertise in the relationship between CSR and the earnings quality of Korean firms with high levels of CSR. Using a multivariate analysis, it investigates whether the ACs that include members with accounting expertise, finance expertise, or supervisory expertise individually affect a firm's decision making. It also examines how ACs with diverse expertise contribute toward improving the financial reporting quality of firms with high levels of CSR. The results demonstrate that when there is a certified accountant in the AC of a firm that practices CSR based on ethical motivation, the earnings management through discretionary accruals is more strictly controlled. This is more effective when the AC comprises members with accounting and non-accounting expertise. This finding implies that the AC plays a positive role in improving the accounting information quality of firms with CSR excellence. Moreover, while the role of accounting experts in the AC is important for maintaining high earnings quality, combining other types of expertise creates synergy.
\end{abstract}

Keywords: CSR; Korea; audit committee; financial reporting

\section{Introduction}

This study examines the role of the financial expertise of an audit committee (AC) in the relationship between corporate social responsibility (CSR) and financial reporting quality for Korean companies.

CSR activities are generally long-term and involve costs that are not directly related to corporate profitability [1]. Therefore, when a company implements CSR, it reflects the management's incentives to do so. Conflicting research results on the relationship between CSR and financial reporting quality lead to the inference that the companies who engage in CSR activities are not necessarily moral and ethical. However, since CSR involves multiple activities, including donations, efforts to improve employee satisfaction, and environmental protection, it is inevitably affected by the cultural and legal environment of the country where the company is located. A series of studies that analyze the CSR status among Korean companies confirm that such activities do not damage the quality of the earnings reported in their financial statements because they perform CSR for the purpose of contributing to the society [2,3].

Moreover, a firm's AC, which is formed by the board of directors, independently monitors and supervises the management's activities, thereby reducing agency costs. This also increases the transparency and reliability of the firm's accounting information, as per the Securities and Exchange Commission (SEC) [4]. In the U.S., the ACs first emerged immediately after the Great Depression, and their role was strengthened by the SarbanesOxley Act (SOX) implemented after the Enron scandal. In accordance with the Commercial 
Act and the Securities and Exchange Act, Korea is also gradually reinforcing its regulations of ACs [5].

ACs often include various financial experts with accounting, finance, or supervisory expertise. AC members with accounting expertise are fully aware of a firm's financial reporting process, based on their specialized knowledge of accounting and external auditing. Members with finance expertise have experience in financial firms and members with supervisory expertise have experience in organizational decision-making. Members with accounting expertise contribute to improving the AC's status and influence in the firm [6].

If AC members' accounting, finance, and supervisory expertise influence corporate behavior individually or in combination with other specialties, they are expected to contribute toward improving the financial reporting quality of the Korean CSR companies. However, it has been reported that corporate governance is not efficiently managed in the East Asian countries where significant shareholders exercise their absolute influence. If an $\mathrm{AC}$ is constructed as a mere formality and fails to properly monitor and supervise management $[7,8]$, then having members with financial expertise will not affect the firm's earnings quality. Therefore, this study's goal is to empirically verify the role of AC members in the relationship between CSR and financial reporting quality.

\section{Literature Review and Hypotheses Testing}

Firms have various motives for practicing CSR: It may help them contribute to society or increase shareholder wealth by enhancing enterprise value. Moreover, some managers practice CSR based on their own personal interests, such as maintaining their reputation or prestige.

Studies suggest that if firms are ethically motivated to contribute to society, they do not adversely affect their earnings quality by engaging in earnings management. However, firms that practice CSR only to maximize enterprise value based on opportunistic incentives may lower their earnings quality via earnings management.

Studies that analyze the relationship between CSR and earnings management have reported conflicting results. In the U.S. firms, Kim et al. [2] found a negative (-) relationship among CSR scores, discretionary accruals, and real activities earnings management. In contrast, Prior et al. [9], who examine firms in 26 countries, show that the firms that practice earnings management also strategically practice CSR. Muttakin et al. [10] analyze firms in Bangladesh to confirm that there is a positive (+) correlation between firms' CSR disclosure levels and earnings management. They argue that the firms whose managers practice CSR based on opportunistic incentives are likely to adopt earnings management. Salewski and Zulch [11] examine the relationship between CSR and earnings management in European countries by applying IFRS and discover that firms with higher levels of CSR were engaged in more earnings management and failed to timely disclose unfavorable factors.

However, CSR involves multiple activities, including donations, efforts to improve employee satisfaction, and environmental protection; thus, it is affected by the cultural and legal environment of the country in which the firm is located. Moon [12] finds that managers of the Korean firms that implement ethical management make fewer discretionary accounting choices, resulting in excellent earnings quality, and emphasizes the need to implement ethical management. Lim and Choi [13] report that the ethical companies that were included in the KEJI index as one of the 200 best CSR companies control accrualbased earnings management. Choi and Moon [3] analyze the relationship between CSR and the earnings quality of Korean firms to discover that the firms included in the KEJI Index with CSR excellence demonstrate less earnings management and higher earnings persistence than other firms. Kim and Jeong [14] examine the relationship between CSR activities and real earnings management for Korean companies. By confirming that companies with superior CSR activities show less real earnings management, they suggest that CSR activities can be useful as an indicator of accounting transparency and sustainable growth. Kim [15] reports a negative relationship between the CSR activities of Korean companies and earnings management and finds that the higher the KEJI index, the greater 
the stock price multiply for earnings per share. The researcher argues that when accounting transparency increases due to less earnings management, the trust of external investors increases; thus, the accounting information of the companies that actively engage in CSR activities is reflected in their relative corporate value. Previous studies report that the Korean companies that actively engage in CSR activities place importance on ethical values and control earnings management or income smoothing, resulting in high accounting transparency.

Moreover, to practice CSR, firms must prioritize establishing management objectives and developing management, audit, and decision-making systems. Corporate governance is at the core of these systems and has a decisive influence on a firm's CSR activities. Thus, sound corporate governance is expected to induce active CSR activities and contribute to corporate performance [16]. Consistent with this expectation, prior research shows that corporate governance has a positive influence on the effectiveness of CSR activities; in Korea, CSR activities and corporate governance exhibit a complementary relationship $[17,18]$. Similarly, Shaukat et al. [19] report that the board's CSR orientation has a positive impact on CSR performance.

The AC is one of the several committees in a firm's board of directors; it serves as a key corporate governance mechanism that aims to increase the reliability of accounting information by monitoring and supervising the firm's financial reporting process. In the U.S., the SOX Section 407 requires listed firms to employ at least one financial expert in their AC. Korea's Securities and Exchange Act also requires that firms have at least one accounting or financial expert in their AC. The literature also suggests that having financial experts in the AC improves earnings quality. Xie et al. [20] discover that the earnings management deteriorates when the $\mathrm{AC}$ has an outside director with experience of a CEO or an investment banker. Bédard et al. [21] report that ACs with financial expertise inhibit firms' earnings management, while Keune and Johnstone [22] argue that the ACs with strong financial expertise are less likely to make critical revisions to the financial statements.

As summarized above, firms with AC members who have financial expertise have higher financial reporting quality because they strictly monitor and supervise the management. Given that CSR activities and corporate governance are expected to have a complementary association, earnings management through the discretionary accruals by firms practicing CSR based on ethical motivation will be more strictly controlled when the AC includes members with financial expertise. Thus, the first hypothesis is formulated as follows:

Hypothesis 1 (H1). The presence of AC members with financial expertise intensifies the positive impact of CSR activities on earnings quality.

The SEC [4] recommends that financial experts in the AC must understand accounting standards and financial statements and determine whether the accounting methods meet the required standards. Simultaneously, they must understand the firm's internal control and financial reporting processes; thus the scope of financial experts is limited to accounting, finance, and supervisory experts.

Many previous studies report that the quality of financial reporting improves when accounting experts are included as members of the AC [23-25], but Cohen et al. [26] emphasize the importance of $\mathrm{AC}$ members with non-accounting expertise. AC members with finance or supervisory expertise can help the members with accounting expertise to improve the AC's status and influence in the firm [6]. Dhaliwal et al. [27] also report that financial reporting quality improves only when there are both accounting and finance experts or all three expert types in the AC. In sum, even though accounting expertise is relatively more important among the types of financial expertise in an $\mathrm{AC}$, the committee is more effective when there are also directors with other areas of expertise that complement each other. Thus, the second hypothesis is formulated as follows: 
Hypothesis 2 (H2). The presence of both accounting and non-accounting experts in an AC intensifies the positive impact of CSR activities on earnings quality.

\section{Materials and Methods}

\subsection{Sample}

Firms listed on the Korea Stock Exchange (KSE) from 2011 to 2015 were selected for this study. The Commercial Act mandates that Korean public firms with total assets of over KRW 2 trillion (approximately USD 1.7 billion) should establish an AC. Moreover, similar to the U.S. SOX requirement, firms must employ at least one AC member with financial expertise. The data on ACs were collected from the firms' annual reports, which are available in the data retrieval system of the Financial Supervisory Service (FSS).

A firm's CSR excellence was identified using its KEJI index. The KEJI evaluates the CSR activities for firms listed on the KSE and announces its list of the top 200 firms based on their KEJI Index. The KEJI evaluates six categories (soundness, fairness, social service activities, customer protection, environmental protection, and employee satisfaction) and sums up each firm's total score out of a total of 100 points. However, since the score is standardized by a formula, the published scores of the top 200 companies exhibit a normal distribution with a small deviation. For example, the average CSR score of the top 200 companies in 2015 was 64 , and the standard deviation was 1.8. Thus, studies on the CSR of Korean firms assess the CSR activity levels of public companies in the securities market by creating a dummy variable that equals to 1 when a company is in the top 200 list in the KEJI Index, and 0 otherwise.

The financial data were extracted from TS-2000. Firms in the financial industry, those without a December fiscal year-end or an AC, and those with missing variables were excluded from the sample. To alleviate the potential effects of outliers, continuous variables were winsorized at the top and bottom $1 \%$. The final sample of this study includes 896 firm-years.

\subsection{Research Model}

This study employs the following regression model to verify the hypotheses. First, we estimate Equation (1) to examine the effects of ACs with financial expertise on the association between CSR and earnings quality. Equation (1) is calculated as follows:

$$
\begin{aligned}
\text { DA } & =\beta_{0}+\beta_{1} \text { CSR }+\beta_{2} \text { CSR } \times \text { ACCCERT }+\beta_{3} \text { CSR } \times \text { ACCPROF } \\
& +\beta_{4} \text { CSR } \times \text { ACCOTHERS }+\beta_{5} \text { CSR } \times \text { FINPROF }+\beta_{6} \text { CSR } \times \text { FINOTHERS } \\
& +\beta_{7} \text { CSR } \times \text { SUP }+\beta_{8} \text { ACCCERT }+\beta_{9} \text { ACCPROF }+\beta_{10} \text { ACCOTHERS } \\
& +\beta_{11} \text { FINPROF }+\beta_{12} \text { FINOTHERS }+\beta_{13} \text { SUP }+\beta_{14} \text { ACIND } \\
& +\beta_{15} \operatorname{lnACACTIVITY~}+\beta_{16} \ln \text { ACTENURE }+\beta_{17} \text { SIZE }+\beta_{18} \text { STDCFO } \\
& +\beta_{19} \text { ZSCORE }+\beta_{20} \text { LOSS }+\beta_{21} \text { TACCt }-1+\beta_{22} \text { BIGAUDITOR } \\
& +\beta_{23} \text { AUDEXPERT }+\beta_{24} \text { CLEAN }+\beta_{25} \ln \text { AGE } \\
& + \text { Industry and year indicators }+\varepsilon .
\end{aligned}
$$

The dependent variable is performance-matched discretionary accruals (DA) [28]. Studies on CSR accounting mainly examine whether the firms that practice CSR negatively affect their earnings quality through earnings management [2,3,9-12]. Thus, this study uses the level of earnings management as a proxy for earnings quality. The most commonly used measure of earnings management is discretionary accruals [3]. Discretionary accruals can be calculated using the Jones model and the modified Jones model, but these measures are closely related to firm performance [28]. Accordingly, following Kothari et al. [28], this study uses performance-matched discretionary accruals, which is estimated after controlling for the return on assets.

The main variables of interest in this study observe the interactions between CSR and $A C s^{\prime}$ financial expertise. This study employs the subtypes of AC financial experts as the proxies for AC financial expertise; ACCCERT, ACCPROF, ACCOTHERS, FINPROF, FINOTHERS, and SUP are the dummy variables observing certified accountants, account- 
ing professors, other accounting experts, finance professors, other finance experts, and supervisory experts, respectively. Using subtypes enables a deeper understanding of the effectiveness of AC financial expertise and its effect on the association between CSR and earnings quality. If the interaction terms between CSR and AC financial experts improve the quality of earnings, the coefficients $\beta_{2}$ to $\beta_{7}$ will be negative.

Next, we estimate Equation (2) to examine the effects of ACs with both accounting and non-accounting expertise on the association between CSR and earnings quality. It is calculated as follows:

$$
\begin{aligned}
\mathrm{DA} & =\beta_{0}+\beta_{1} \mathrm{CSR}+\beta_{2} \mathrm{CSR} \times \text { ACCEXPONLY } \\
& +\beta_{3} \mathrm{CSR} \times \text { ACCANDANOTHER }+\beta_{4} \mathrm{CSR} \times \text { ALL }+\beta_{5} \text { ACCEXPONLY } \\
& +\beta_{6} \text { ACCANDANOTHER }+\beta_{7} \text { ALL }+\beta_{8} \text { ACIND }+\beta_{9} \ln \text { ACACTIVITY } \\
& +\beta_{10} \ln \text { ACTENURE }+\beta_{11} \text { SIZE }+\beta_{12} \text { STDCFO }+\beta_{13} \text { ZSCORE }+\beta_{14} \text { LOSS } \\
& +\beta_{15} \text { TACCt }-1+\beta_{16} \text { BIGAUDITOR }+\beta_{17} \text { AUDEXPERT }+\beta_{18} \text { CLEAN } \\
& +\beta_{19} \operatorname{lnAGE~}+\text { Industry and year indicators }+\varepsilon .
\end{aligned}
$$

Here, AC expertise variables represent a mixture of AC financial experts. Specifically, ACCEXPONLY, ACCANDANOTHER, and ALL are dummy variables representing ACs with only accounting experts, accounting experts and either finance or supervisory experts, and with all three types of financial experts. Accounting (finance) experts have experience in the accounting (finance) field and are considered as certified accountants, controllers, chief financial officers, or accounting professors (bankers, analysts, fund managers, or finance professors). If the interactions between CSR and the mixture of financial experts on ACs enhance earnings quality, the coefficients $\beta_{2}$ to $\beta_{4}$ will be negative.

Similar to previous studies $[29,30]$, other AC and firm characteristics that affect earnings quality are also controlled for in this study. The study includes AC independence (ACIND), the natural logarithm of the number of meetings held by ACs during the fiscal year (lnACACTIVITY), and the natural logarithm of the average number of years AC members have served as the directors of a firm (lnACTENURE). In addition, firm size (SIZE), corporate financial risk (ZSCORE), profitability (LOSS), and firm age (lnAGE) are controlled. This study also controls for the three-year standard deviation of operating cash flows (STDCFO) and lagged total accruals (TACCt-1) to minimize the discretionary accrual measurement errors and control accrual reversal. Big $\mathrm{N}$ auditors (BIGAUDITOR), industry expert auditors (AUDEXPERT), and audit opinion (CLEAN) are included to control for auditor characteristics. The definitions of the variables are listed in the Appendix A in Table A1. Finally, the industry and year indicators are included to control for the differences in the industry and year characteristics.

\section{Results}

\subsection{Descriptive Statistics and Correlation Analysis}

Table 1 presents the descriptive statistics of the variables used in this study. The mean of CSR is 0.376 , and the average ratios of certified accountants (ACCCERT), accounting professors (ACCPROF), and accounting experts (excluding ACCCERT and ACCPROF), such as the controller and the chief financial officer (ACCOTHERS) in the AC are $19.5 \%$, $12.6 \%$, and $20.5 \%$, respectively. The average ratios of finance professors (FINPROF), finance experts (excluding FINPROF), such as bankers and analysts (FINOTHERS), and supervisory experts such as CEOs among AC members are $8.5 \%, 12.1 \%$, and $42.5 \%$, respectively. In terms of AC composition, $32 \%, 15.3 \%$, and $2.0 \%$ of the whole sample have an AC comprising only accounting experts (ACCEXPONLY), accounting experts and finance or supervisory experts (ACCANDANOTHER), and all three types of financial experts (ALL), respectively.

Table 2 reports the Pearson correlation coefficients for the variables included in the research model. DA is significantly negatively $(-)$ correlated with CSR. ACCOTHERS also shows a significantly negative $(-)$ correlation with DA, but the other expertise variables have no significant correlations with DA. Total accruals at the beginning of the year (TACCt- 
1) are significantly positively $(+)$ correlated with DA, whereas auditors with industrial expertise (AUDEXPERT) and firm age (lnAGE) have a significantly negative $(-)$ correlation with DA. However, these results are based on univariate analysis, and the hypotheses were also tested through multivariate analysis, controlling for other variables that may affect DA. Furthermore, the variance inflation factor is less than 10 . Thus, it is unlikely that the results will be distorted by the problem of multicollinearity.

Table 1. Descriptive statistics.

\begin{tabular}{|c|c|c|c|c|c|}
\hline Variable & Mean & Std. Dev. & Q1 & Median & Q3 \\
\hline $\mathrm{DA}$ & 0.000 & 0.085 & -0.042 & -0.003 & 0.048 \\
\hline CSR & 0.376 & 0.485 & 0.000 & 0.000 & 1.000 \\
\hline ACCCERT & 0.195 & 0.397 & 0.000 & 0.000 & 0.000 \\
\hline ACCPROF & 0.126 & 0.332 & 0.000 & 0.000 & 0.000 \\
\hline ACCOTHERS & 0.205 & 0.404 & 0.000 & 0.000 & 0.000 \\
\hline FINPROF & 0.085 & 0.279 & 0.000 & 0.000 & 0.000 \\
\hline FINOTHERS & 0.121 & 0.326 & 0.000 & 0.000 & 0.000 \\
\hline SUP & 0.425 & 0.495 & 0.000 & 0.000 & 1.000 \\
\hline ACCEXPONLY & 0.320 & 0.467 & 0.000 & 0.000 & 1.000 \\
\hline ACCANDANOTHER & 0.153 & 0.360 & 0.000 & 0.000 & 0.000 \\
\hline ALL & 0.020 & 0.140 & 0.000 & 0.000 & 0.000 \\
\hline ACIND & 0.883 & 0.322 & 1.000 & 1.000 & 1.000 \\
\hline lnACACTIVITY & 1.397 & 0.667 & 1.099 & 1.386 & 1.792 \\
\hline lnACTENURE & 1.007 & 0.578 & 0.693 & 0.981 & 1.386 \\
\hline SIZE & 21.065 & 1.611 & 19.657 & 21.109 & 22.266 \\
\hline STDCFO & 0.049 & 0.041 & 0.021 & 0.038 & 0.064 \\
\hline ZSCORE & 3.707 & 4.202 & 1.601 & 2.498 & 4.113 \\
\hline LOSS & 0.209 & 0.407 & 0.000 & 0.000 & 0.000 \\
\hline TACCt-1 & -0.017 & 0.070 & -0.051 & -0.018 & 0.011 \\
\hline BIGAUDITOR & 0.873 & 0.333 & 1.000 & 1.000 & 1.000 \\
\hline AUDEXPERT & 0.335 & 0.472 & 0.000 & 0.000 & 1.000 \\
\hline CLEAN & 0.998 & 0.047 & 1.000 & 1.000 & 1.000 \\
\hline $\ln \mathrm{AGE}$ & 2.712 & 1.019 & 2.164 & 3.064 & 3.562 \\
\hline
\end{tabular}

Note: These variables are used in the regression model and are defined in Table A1, Appendix A.

\subsection{Results of the Multivariate Analysis}

Table 3 reports the results of the multivariate analysis used to test Hypothesis 1 ; the analysis uses standard errors clustered at the firm and year levels [31,32]. First, from Column (1), which presents results of the regression analysis of CSR and earnings quality, the coefficient of CSR is observed to be negative (-) and significant. This is consistent with the results obtained in previous studies concerning Korea; they observe that firms with higher CSR levels make more effort to control earnings quality [3,12]. Columns (2)-(7) present the results of the empirical analysis with an addition of the financial expertise variables. In Columns (2)-(7), the coefficient of CSR is also negative (-) and significant in all the columns except Column (2). For the interaction terms of CSR and AC expertise, only the coefficient of CSR $\times$ ACCCERT is observed to have a significantly negative $(-)$ value. This implies that when there is a certified accountant in the AC, the discretionary accrual earnings management of the firms practicing CSR based on ethical motivation is more strictly controlled. This finding is consistent with the results obtained in prior studies, showing that ACs with accounting expertise enhance the quality of financial reporting [23-25]; furthermore, they are more likely to hire an industry expert auditor and pay higher audit fees [6]. However, contrary to prior studies, this study's results show the relative effectiveness of certified accountants among the accounting experts in ACs. This finding is important, as little is known about which subtypes of financial experts benefit ACs. In addition, these results provide new evidence that $\mathrm{AC}$ accounting expertise has a positive impact on the relationship between CSR and earnings quality. 
Table 2. Correlation analysis.

\begin{tabular}{|c|c|c|c|c|c|c|c|c|c|c|c|c|c|c|c|c|c|c|c|c|}
\hline Variable & (1) & (2) & (3) & (4) & (5) & (6) & (7) & (8) & (9) & (10) & (11) & (12) & (13) & (14) & (15) & (16) & (17) & (18) & (19) & (20) \\
\hline (1) DA & 1.00 & & & & & & & & & & & & & & & & & & & \\
\hline $\begin{array}{l}\text { (2) CSR } \\
\text { (3) ACCCERT }\end{array}$ & $\begin{array}{c}-\mathbf{0 . 0 9} \\
0.05\end{array}$ & $\begin{array}{l}1.00 \\
0.05\end{array}$ & 1.00 & & & & & & & & & & & & & & & & & \\
\hline (4) ACCPROF & 0.02 & 0.03 & -0.18 & 1.00 & & & & & & & & & & & & & & & & \\
\hline (5) ACCOTHERS & -0.06 & 0.04 & -0.14 & -0.08 & 1.00 & & & & & & & & & & & & & & & \\
\hline (6) FINPROF & -0.05 & -0.03 & -0.08 & -0.03 & -0.04 & 1.00 & & & & & & & & & & & & & & \\
\hline (7) FINOTHERS & 0.03 & -0.08 & -0.10 & -0.10 & -0.13 & -0.00 & 1.00 & & & & & & & & & & & & & \\
\hline (8) SUP & -0.00 & -0.02 & -0.20 & -0.08 & -0.12 & 0.04 & -0.04 & 1.00 & & & & & & & & & & & & \\
\hline (9) ACIND & -0.01 & -0.03 & 0.05 & 0.03 & 0.09 & 0.05 & 0.05 & -0.02 & 1.00 & & & & & & & & & & & \\
\hline (10) $\ln$ ACACTIVITY & -0.05 & 0.02 & -0.02 & 0.08 & -0.05 & -0.01 & -0.00 & 0.00 & 0.05 & 1.00 & & & & & & & & & & \\
\hline (11) $\ln$ ACTENURE & -0.02 & 0.06 & -0.04 & 0.03 & -0.05 & -0.03 & -0.02 & -0.06 & -0.08 & 0.04 & 1.00 & & & & & & & & & \\
\hline (12) SIZE & -0.04 & -0.16 & -0.22 & -0.02 & 0.12 & 0.19 & 0.00 & -0.05 & 0.31 & 0.08 & 0.00 & 1.00 & & & & & & & & \\
\hline (13) STDCFO & -0.00 & -0.09 & 0.05 & -0.02 & -0.11 & -0.04 & 0.06 & 0.04 & -0.05 & 0.03 & -0.10 & -0.02 & 1.00 & & & & & & & \\
\hline (14) ZSCORE & -0.00 & 0.14 & 0.19 & 0.11 & -0.02 & -0.01 & -0.09 & -0.07 & -0.11 & -0.09 & -0.00 & -0.13 & -0.06 & 1.00 & & & & & & \\
\hline (15) LOSS & 0.02 & -0.33 & -0.07 & 0.00 & -0.11 & 0.02 & 0.12 & 0.08 & -0.00 & 0.03 & 0.02 & 0.05 & 0.09 & -0.29 & 1.00 & & & & & \\
\hline (16) TACCt-1 & 0.11 & -0.05 & 0.03 & -0.04 & 0.05 & -0.06 & -0.06 & 0.02 & 0.02 & -0.02 & -0.04 & -0.01 & 0.10 & 0.11 & -0.05 & 1.00 & & & & \\
\hline (17) BIGAUDITOR & -0.03 & -0.05 & 0.00 & 0.11 & 0.03 & 0.09 & -0.10 & 0.02 & 0.19 & 0.03 & -0.13 & 0.35 & -0.06 & 0.12 & -0.13 & 0.07 & 1.00 & & & \\
\hline (18) AUDEXPERT & -0.08 & -0.09 & -0.09 & 0.04 & -0.00 & 0.06 & -0.07 & 0.03 & 0.11 & 0.02 & -0.08 & 0.30 & -0.04 & 0.01 & -0.00 & -0.03 & 0.27 & 1.00 & & \\
\hline (19) CLEAN & 0.00 & 0.04 & 0.02 & 0.02 & 0.02 & 0.01 & -0.13 & -0.01 & -0.02 & -0.02 & 0.06 & 0.01 & 0.01 & 0.05 & -0.09 & 0.01 & -0.02 & 0.03 & 1.00 & \\
\hline (20) $\ln A G E$ & -0.08 & -0.02 & -0.13 & -0.02 & 0.07 & 0.02 & 0.12 & -0.02 & 0.05 & 0.08 & 0.26 & 0.10 & -0.16 & -0.09 & 0.15 & -0.04 & -0.06 & -0.02 & 0.00 & 1.00 \\
\hline
\end{tabular}

Note: This table shows the Pearson correlations. The numbers presented in bold indicate significance at $p \leq 0.10$. The variables are listed in the Appendix A, Table A1. 
Table 3. Corporate social responsibility (CSR), audit committee (AC) financial expertise, and earnings quality.

\begin{tabular}{|c|c|c|c|c|c|c|c|c|}
\hline \multirow{2}{*}{ Variable } & \multicolumn{8}{|c|}{ Dependent Variable $=$ DA } \\
\hline & (1) & (2) & (3) & (4) & (5) & (6) & (7) & (8) \\
\hline Constant & $\begin{array}{c}0.017 \\
(0.173)\end{array}$ & $\begin{array}{c}0.012 \\
(0.129)\end{array}$ & $\begin{array}{c}0.019^{* * *} \\
(3.998)\end{array}$ & $\begin{array}{c}0.012 \\
(0.129)\end{array}$ & $\begin{array}{c}0.007 \\
(0.077)\end{array}$ & $\begin{array}{c}0.008 \\
(0.082)\end{array}$ & $\begin{array}{c}0.018 \\
(0.191)\end{array}$ & $\begin{array}{c}-0.013 \\
(-0.578)\end{array}$ \\
\hline & $-0.019 * * *$ & $\begin{array}{l}(0.129) \\
-0.014\end{array}$ & $-0.019 * * *$ & $-0.022 * * *$ & $-0.019^{* * *}$ & $\begin{array}{l}(0.082) \\
-0.018^{* * *}\end{array}$ & $-0.024^{* * *}$ & $\begin{array}{l}(-0.5 / 8) \\
-0.017 * *\end{array}$ \\
\hline CSR & $(-2.885)$ & $(-1.616)$ & $(-3.006)$ & $(-3.769)$ & $(-2.702)$ & $(-2.882)$ & $(-2.981)$ & $(-2.127)$ \\
\hline $\mathrm{CSR} \times$ ACCCERT & & $\begin{array}{l}-0.023^{* *} \\
(-2.511)\end{array}$ & & & & & & $\begin{array}{c}-0.021 \text { *** } \\
(-2.797)\end{array}$ \\
\hline $\mathrm{CSR} \times \mathrm{ACCPROF}$ & & & $\begin{array}{c}-0.009 \\
(-0.461)\end{array}$ & & & & & $\begin{array}{l}-0.013 \\
(-0.690)\end{array}$ \\
\hline $\mathrm{CSR} \times$ ACCOTHERS & & & & $\begin{array}{c}0.014 \\
(1.050)\end{array}$ & & & & $\begin{array}{l}0.010 \\
(0.797)\end{array}$ \\
\hline $\mathrm{CSR} \times$ FINPROF & & & & & $\begin{array}{c}-0.009 \\
(-0.592)\end{array}$ & & & $\begin{array}{c}-0.009 \\
(-0.580)\end{array}$ \\
\hline $\mathrm{CSR} \times$ FINOTHERS & & & & & & $\begin{array}{c}-0.009 \\
(-0.516)\end{array}$ & & $\begin{array}{l}-0.009 \\
(-0.517)\end{array}$ \\
\hline $\mathrm{CSR} \times \mathrm{SUP}$ & & & & & & & $\begin{array}{c}0.012 \\
(0.737)\end{array}$ & $\begin{array}{c}0.009 \\
(0.511)\end{array}$ \\
\hline ACCCERT & & $\begin{array}{c}0.017 \\
(1.330)\end{array}$ & & & & & & $\begin{array}{c}0.017 \\
(1.631)\end{array}$ \\
\hline ACCPROF & & & $\begin{array}{l}0.011^{*} \\
(1.685)\end{array}$ & & & & & $\begin{array}{c}0.013 \\
(1.541)\end{array}$ \\
\hline ACCOTHERS & & & & $\begin{array}{l}-0.016 \text { ** } \\
(-2.281)\end{array}$ & & & & $\begin{array}{l}-0.013^{*} \\
(-1.849)\end{array}$ \\
\hline FINPROF & & & & & $\begin{array}{c}-0.014 \\
(-0.874)\end{array}$ & & & $\begin{array}{l}-0.013 \\
(-0.781)\end{array}$ \\
\hline FINOTHERS & & & & & & $\begin{array}{c}0.009 \\
(0.446)\end{array}$ & & $\begin{array}{c}0.009 \\
(0.416)\end{array}$ \\
\hline SUP & & & & & & & $\begin{array}{c}-0.005 \\
(-0.463)\end{array}$ & $\begin{array}{c}-0.003 \\
(-0.224)\end{array}$ \\
\hline ACIND & $\begin{array}{c}0.008 \\
(0.835)\end{array}$ & $\begin{array}{c}0.007 \\
(0.712)\end{array}$ & $\begin{array}{c}0.008 \\
(0.842)\end{array}$ & $\begin{array}{c}0.009 \\
(0.864)\end{array}$ & $\begin{array}{c}0.008 \\
(0.884)\end{array}$ & $\begin{array}{c}0.008 \\
(0.758)\end{array}$ & $\begin{array}{c}0.008 \\
(0.770)\end{array}$ & $\begin{array}{l}0.006 \\
(0.641)\end{array}$ \\
\hline $\ln A C A C T I V I T Y$ & $\begin{array}{l}-0.005 \\
(-1.142)\end{array}$ & $\begin{array}{c}-0.004 \\
(-1.033)\end{array}$ & $\begin{array}{c}-0.005 \\
(-1.285)\end{array}$ & $\begin{array}{c}-0.006 \\
(-1.245)\end{array}$ & $\begin{array}{l}-0.005 \\
(-1.300)\end{array}$ & $\begin{array}{c}-0.005 \\
(-1.154)\end{array}$ & $\begin{array}{c}-0.005 \\
(-1.148)\end{array}$ & $\begin{array}{c}-0.006 \\
(-1.552)\end{array}$ \\
\hline lnACTENURE & $\begin{array}{l}0.003 \\
(0.634)\end{array}$ & $\begin{array}{c}0.002 \\
(0.648)\end{array}$ & $\begin{array}{c}0.002 \\
(0.610)\end{array}$ & $\begin{array}{c}0.002 \\
(0.396)\end{array}$ & $\begin{array}{l}0.002 \\
(0.621)\end{array}$ & $\begin{array}{l}0.003 \\
(0.593)\end{array}$ & $\begin{array}{l}0.003 \\
(0.678)\end{array}$ & $\begin{array}{l}0.002 \\
(0.402)\end{array}$ \\
\hline SIZE & $\begin{array}{l}-0.004^{*} \\
(-1.734)\end{array}$ & $\begin{array}{c}-0.004 \\
(-1.502)\end{array}$ & $\begin{array}{l}-0.004 * \\
(-1.772)\end{array}$ & $\begin{array}{l}-0.003 \\
(-1.578)\end{array}$ & $\begin{array}{l}-0.003 \\
(-1.565)\end{array}$ & $\begin{array}{l}-0.004^{*} \\
(-1.790)\end{array}$ & $\begin{array}{l}-0.004^{*} \\
(-1.883)\end{array}$ & $\begin{array}{l}-0.003 * \\
(-1.705)\end{array}$ \\
\hline STDCFO & $\begin{array}{c}-0.120 * * * \\
(-3.678)\end{array}$ & $\begin{array}{c}-0.139 * * * \\
(-4.794)\end{array}$ & $\begin{array}{l}-0.121^{* * *} \\
(-3.702)\end{array}$ & $\begin{array}{c}-0.127 * * * \\
(-3.781)\end{array}$ & $\begin{array}{l}-0.125^{* * * *} \\
(-17.321)\end{array}$ & $\begin{array}{l}-0.127 * * * \\
(-4.164)\end{array}$ & $\begin{array}{c}-0.118^{* * *} \\
(-3.331)\end{array}$ & $\begin{array}{c}-0.151 * * * \\
(-6.899)\end{array}$ \\
\hline ZSCORE & $\begin{array}{l}-0.000 \\
(-0.017)\end{array}$ & $\begin{array}{l}-0.000 \\
(-0.856)\end{array}$ & $\begin{array}{l}-0.000 \\
(-0.064)\end{array}$ & $\begin{array}{l}-0.000 \\
(-0.142)\end{array}$ & $\begin{array}{l}0.000 \\
(0.143)\end{array}$ & $\begin{array}{l}-0.000 \\
(-0.047)\end{array}$ & $\begin{array}{l}-0.000 \\
(-0.123)\end{array}$ & $\begin{array}{l}-0.000 \\
(-0.573)\end{array}$ \\
\hline LOSS & $\begin{array}{l}-0.006 \\
(-0.818)\end{array}$ & $\begin{array}{l}-0.005 \\
(-0.617)\end{array}$ & $\begin{array}{l}-0.006 \\
(-0.857)\end{array}$ & $\begin{array}{l}-0.007 \\
(-0.945)\end{array}$ & $\begin{array}{l}-0.006 \\
(-0.838)\end{array}$ & $\begin{array}{l}-0.006 \\
(-0.810)\end{array}$ & $\begin{array}{l}-0.005 \\
(-0.712)\end{array}$ & $\begin{array}{l}-0.006 \\
(-0.740)\end{array}$ \\
\hline TACCt-1 & $\begin{array}{l}0.101 * \\
(1.846)\end{array}$ & $\begin{array}{l}0.102 \text { * } \\
(1.859)\end{array}$ & $\begin{array}{l}0.104 * \\
(1.906)\end{array}$ & $\begin{array}{l}0.106^{*} \\
(1.897)\end{array}$ & $0.097 *$ & $\begin{array}{l}0.104 * \\
(1.944)\end{array}$ & $\begin{array}{l}0.101 * \\
(1.863)\end{array}$ & $\begin{array}{l}0.106^{*} \\
(1.938)\end{array}$ \\
\hline BIGAUDITOR & $\begin{array}{c}-0.004 \\
(-0.272)\end{array}$ & $\begin{array}{c}-0.002 \\
(-0.158)\end{array}$ & $\begin{array}{c}-0.004 \\
(-0.328)\end{array}$ & $\begin{array}{c}-0.004 \\
(-0.296)\end{array}$ & $\begin{array}{c}-0.003 \\
(-0.236)\end{array}$ & $\begin{array}{l}-0.003 \\
(-0.240)\end{array}$ & $\begin{array}{c}-0.003 \\
(-0.236)\end{array}$ & $\begin{array}{c}-0.002 \\
(-0.171)\end{array}$ \\
\hline AUDEXPERT & $\begin{array}{l}-0.014 * * \\
(-2.014)\end{array}$ & $\begin{array}{l}-0.014 * * \\
(-2.117)\end{array}$ & $\begin{array}{l}-0.014 * * \\
(-2.013)\end{array}$ & $\begin{array}{l}-0.014 * * \\
(-2.127)\end{array}$ & $\begin{array}{l}-0.014 \text { ** } \\
(-2.009)\end{array}$ & $\begin{array}{l}-0.0144^{* *} \\
(-2.008)\end{array}$ & $\begin{array}{l}-0.014 * * \\
(-2.022)\end{array}$ & $\begin{array}{l}-0.014 \text { ** } \\
(-2.351)\end{array}$ \\
\hline CLEAN & $\begin{array}{l}0.013 \\
(0.649)\end{array}$ & $\begin{array}{c}0.011 \\
(0.583)\end{array}$ & $\begin{array}{l}0.011 \\
(0.522)\end{array}$ & $\begin{array}{l}0.014 \\
(0.714)\end{array}$ & $\begin{array}{l}0.015 \\
(0.748)\end{array}$ & $\begin{array}{l}0.020 \\
(0.879)\end{array}$ & $\begin{array}{l}0.012 \\
(0.582)\end{array}$ & $\begin{array}{l}0.018 \\
(0.733)\end{array}$ \\
\hline $\ln \mathrm{AGE}$ & $\begin{array}{c}-0.007^{* * *} \\
(-3.127)\end{array}$ & $\begin{array}{c}-0.007^{* * *} \\
(-3.086)\end{array}$ & $\begin{array}{c}-0.007^{* * *} \\
(-3.132)\end{array}$ & $\begin{array}{c}-0.007^{* * *} \\
(-2.939)\end{array}$ & $\begin{array}{c}-0.007^{* * * *} \\
(-3.188)\end{array}$ & $\begin{array}{c}-0.007 * * * \\
(-3.281)\end{array}$ & $\begin{array}{c}-0.007^{* * * *} \\
(-3.100)\end{array}$ & $\begin{array}{c}-0.007^{* * *} \\
(-3.280)\end{array}$ \\
\hline Industry/Year fixed effects & Yes & Yes & Yes & Yes & Yes & Yes & Yes & Yes \\
\hline Clustering & Firm-years & Firm-years & Firm-years & Firm-years & Firm-years & Firm-years & Firm-years & Firm-years \\
\hline Observations & 896 & 896 & 896 & 896 & 896 & 896 & 896 & 896 \\
\hline Adjusted R2 & 0.045 & 0.046 & 0.044 & 0.046 & 0.046 & 0.043 & 0.044 & 0.043 \\
\hline
\end{tabular}

Note: The symbols ***, and ${ }^{* * *}$ denote significance at the $0.10,0.05$, and 0.01 levels, respectively (all two-tailed tests). The variables are presented in the Appendix A, Table A1.

Column (8) reports the results of the empirical analysis using Equation (1). The results are qualitatively similar to those presented in the first seven columns, including the case of Column (1), which includes all the AC expertise variables. More specifically, the coefficient of CSR is significantly negative, as is the coefficient of CSR $\times$ ACCCERT. In contrast, the interaction terms of CSR and the other financial expertise variables are not significant. In summary, the results presented in Columns (1)-(8) show that the firms that practice CSR based on ethical motivation demonstrate improved earnings quality. Moreover, their earnings quality is further improved when they employ a certified accountant as an AC member. This indicates that the influence of financial experts on the relationship between CSR and earnings quality varies depending on the qualifications of the financial experts. 
This supports the argument that each subtype of the AC financial experts has different experiences, knowledge, and skills, which may have different impacts on AC effectiveness.

Table 4 reports the results of the empirical analyses for Hypothesis 2. Columns (1) and (2) present the results of adding variables that represent each mixture of AC financial experts that are included in Equation (2). As in Table 3, CSR has a significantly negative (-) coefficient. For the interaction terms of CSR and AC expertise, CSR $\times$ ACCANDANOTHER has a significantly negative $(-)$ coefficient. This implies that when there are both accounting and non-accounting experts in the $\mathrm{AC}$, the financial expertise of the $\mathrm{AC}$ has a positive effect on the relationship between CSR and earnings quality. Untabulated results show that the coefficient of CSR $\times$ ALL has a significantly positive (+) value. However, this result should be interpreted with caution because the statistical power is low due to the extremely small sample of firms with ALL. Column (3) reports the results based on Equation (2); these results are similar to the results in Columns (1) and (2). More specifically, CSR again has a significantly negative coefficient, and the coefficient of CSR $\times$ ACCANDANOTHER is also significantly negative. In sum, an AC is more effective when it is comprised of both members with accounting expertise and members with other types of expertise. These results are consistent with those of previous studies that find that AC's effectiveness improves when it comprises members with diverse experiences and skill sets $[26,27]$. Song et al. [6] also show a similar evidence in the context of Korea: an AC with both accounting and nonaccounting financial expertise is more likely to hire an industry expert auditor and pay higher audit fees. However, unlike prior research, the results of this study also suggests that an AC's effect on the relationship between CSR and earnings quality varies depending on the detailed composition of the financial expertise in the AC.

\subsection{Additional Analysis}

In the main regression equation, the combination of financial expertise in the $\mathrm{AC}$ was analyzed with a focus on accounting expertise. In the additional analyses, the following seven variables for combinations of financial expertise were used, with a focus on accounting, finance, and supervisory expertise. First, ACCONLY, FINONLY, and SUPONLY are dummy variables indicating that the $\mathrm{AC}$ has only accounting expertise, only finance expertise, and only supervisory expertise, respectively. Next, ACCFIN, ACCSUP, and FINSUP are dummy variables indicating that the AC has both accounting and finance expertise, both accounting and supervisory expertise, and both finance and supervisory expertise, respectively. Finally, ALL is a dummy variable indicating an AC that includes accounting, finance, and supervisory expertise.

Columns (1)-(6) in Table 5 present the analysis results using the variables that represent each mixture of AC financial expertise; Column (7) shows the results of the analysis in which all the seven variables are included in the regression equation. The results in Table 5 demonstrate that the coefficient of CSR has a significantly negative (-) value, consistent with the findings in Table 4. Moreover, for the interaction terms of CSR and AC expertise, CSR $\times$ FINONLY and CSR $\times$ ACCFIN have significantly negative $(-)$ coefficients. This indicates that when the AC comprises only finance experts, or both accounting and finance experts, the positive effect of the AC on the relation between CSR activities and earnings quality is intensified. Therefore, the effectiveness of ACs established in the firms that practice CSR based on ethical motivation varies depending on the composition of the $\mathrm{AC}^{\prime} \mathrm{s}$ financial expertise. 
Table 4. Corporate social responsibility (CSR), audit committee (AC) financial expertise mixture, and earnings quality.

\begin{tabular}{|c|c|c|c|}
\hline \multirow{2}{*}{ Variable } & \multicolumn{3}{|c|}{ Dependent Variable $=$ DA } \\
\hline & (1) & (2) & (3) \\
\hline Constant & $\begin{array}{l}0.018^{* * *} \\
(3.611)\end{array}$ & $\begin{array}{c}0.018 \\
(0.181)\end{array}$ & $\begin{array}{c}0.021 \\
(0.818)\end{array}$ \\
\hline CSR & $\begin{array}{l}-0.020^{* *} \\
(-2.394)\end{array}$ & $\begin{array}{l}-0.015^{* *} \\
(-2.258)\end{array}$ & $\begin{array}{l}-0.016^{* *} \\
(-2.320)\end{array}$ \\
\hline $\mathrm{CSR} \times \mathrm{ACCONLY}$ & $\begin{array}{l}0.003 \\
(0.205)\end{array}$ & & $\begin{array}{l}-0.002 \\
(-0.175)\end{array}$ \\
\hline $\mathrm{CSR} \times$ ACCANDANOTHER & & $\begin{array}{l}-0.033^{* *} \\
(-2.175)\end{array}$ & $\begin{array}{l}-0.031^{* *} \\
(-2.254)\end{array}$ \\
\hline $\mathrm{CSR} \times \mathrm{ALL}$ & & & $\begin{array}{c}0.085^{* * *} \\
(5.180)\end{array}$ \\
\hline ACCONLY & $\begin{array}{l}-0.003 \\
(-0.239)\end{array}$ & & $\begin{array}{l}-0.000 \\
(-0.002)\end{array}$ \\
\hline ACCANDANOTHER & & $\begin{array}{c}0.027^{* *} \\
(2.243)\end{array}$ & $\begin{array}{c}0.025^{* *} \\
(2.492)\end{array}$ \\
\hline ALL & & & $\begin{array}{c}-0.066 * * * \\
(-2.680)\end{array}$ \\
\hline ACIND & $\begin{array}{c}0.009 \\
(0.892)\end{array}$ & $\begin{array}{c}0.009 \\
(0.940)\end{array}$ & $\begin{array}{l}0.010 \\
(1.024)\end{array}$ \\
\hline $\ln A C A C T I V I T Y$ & $\begin{array}{l}-0.005 \\
(-1.090)\end{array}$ & $\begin{array}{l}-0.005 \\
(-1.104)\end{array}$ & $\begin{array}{l}-0.005 \\
(-1.132)\end{array}$ \\
\hline $\ln A C T E N U R E$ & $\begin{array}{l}0.003 \\
(0.625)\end{array}$ & $\begin{array}{c}0.004 \\
(0.855)\end{array}$ & $\begin{array}{l}0.003 \\
(0.752)\end{array}$ \\
\hline SIZE & $\begin{array}{l}-0.004^{*} \\
(-1.734)\end{array}$ & $\begin{array}{l}-0.004^{*} \\
(-1.867)\end{array}$ & $\begin{array}{l}-0.004 * * \\
(-2.156)\end{array}$ \\
\hline STDCFO & $\begin{array}{l}-0.120^{* * *} \\
(-3.511)\end{array}$ & $\begin{array}{l}-0.132^{* * *} \\
(-4.469)\end{array}$ & $\begin{array}{l}-0.140 * * * \\
(-5.666)\end{array}$ \\
\hline ZSCORE & $\begin{array}{c}0.000 \\
(0.077)\end{array}$ & $\begin{array}{l}-0.000 \\
(-0.276)\end{array}$ & $\begin{array}{l}-0.000 \\
(-0.294)\end{array}$ \\
\hline LOSS & $\begin{array}{l}-0.006 \\
(-0.774)\end{array}$ & $\begin{array}{l}-0.006 \\
(-0.679)\end{array}$ & $\begin{array}{l}-0.007 \\
(-0.733)\end{array}$ \\
\hline TACCt-1 & $\begin{array}{l}0.102 * \\
(1.912)\end{array}$ & $\begin{array}{l}0.108^{* *} \\
(2.153)\end{array}$ & $\begin{array}{l}0.107^{* *} \\
(2.160)\end{array}$ \\
\hline BIGAUDITOR & $\begin{array}{l}-0.004 \\
(-0.276)\end{array}$ & $\begin{array}{l}-0.005 \\
(-0.410)\end{array}$ & $\begin{array}{l}-0.005 \\
(-0.350)\end{array}$ \\
\hline AUDEXPERT & $\begin{array}{l}-0.014^{* *} \\
(-2.015)\end{array}$ & $\begin{array}{l}-0.015^{* *} \\
(-2.068)\end{array}$ & $\begin{array}{l}-0.014^{* *} \\
(-1.999)\end{array}$ \\
\hline CLEAN & $\begin{array}{c}0.013 \\
(0.703)\end{array}$ & $\begin{array}{c}0.008 \\
(0.357)\end{array}$ & $\begin{array}{l}0.010 \\
(0.425)\end{array}$ \\
\hline $\ln \mathrm{AGE}$ & $\begin{array}{l}-0.007^{* * *} \\
(-2.992)\end{array}$ & $\begin{array}{l}-0.007^{* * *} \\
(-3.104)\end{array}$ & $\begin{array}{l}-0.007 * * * \\
(-3.288)\end{array}$ \\
\hline Industry/Year fixed effects & $\begin{array}{l}\text { Yes } \\
\text { Yes }\end{array}$ & $\begin{array}{l}\text { Yes } \\
\text { Yes }\end{array}$ & $\begin{array}{l}\text { Yes } \\
\text { Y.200) }\end{array}$ \\
\hline $\begin{array}{l}\text { Clustering } \\
\text { Observations } \\
\text { Adjusted R2 }\end{array}$ & $\begin{array}{c}\text { Firm-years } \\
896 \\
0.043\end{array}$ & $\begin{array}{c}\text { Firm-years } \\
896 \\
0.050\end{array}$ & $\begin{array}{c}\text { Firm, Year } \\
896 \\
0.054\end{array}$ \\
\hline
\end{tabular}

Note: The symbols ${ }^{*}, * *$, and ${ }^{* * *}$ denote significance at $0.10,0.05$, and 0.01 levels, respectively (all two-tailed tests) The variables are presented in the Appendix A, Table A1.

Table 5. Alternative measures of AC financial expertise mixture.

\begin{tabular}{|c|c|c|c|c|c|c|c|}
\hline \multirow{2}{*}{ Variable } & \multicolumn{7}{|c|}{ Dependent Variable $=$ DA } \\
\hline & (1) & (2) & (3) & (4) & (5) & (6) & (7) \\
\hline Constant & $\begin{array}{l}0.018^{* * *} \\
(3.611)\end{array}$ & $\begin{array}{c}0.019 \\
(0.197)\end{array}$ & $\begin{array}{c}0.020 \\
(0.204)\end{array}$ & $\begin{array}{c}0.025 \\
(1.149)\end{array}$ & $\begin{array}{c}0.019 \\
(0.202)\end{array}$ & $\begin{array}{c}0.020 * * * \\
(3.565)\end{array}$ & $\begin{array}{c}0.038 \\
(1.223)\end{array}$ \\
\hline CSR & $\begin{array}{l}-0.020^{* *} \\
(-2.394)\end{array}$ & $\begin{array}{l}-0.018^{* *} \\
(-2.459)\end{array}$ & $\begin{array}{l}-0.023^{* * *} \\
(-3.807)\end{array}$ & $\begin{array}{l}-0.018^{* * *} \\
(-2.913)\end{array}$ & $\begin{array}{l}-0.016^{* *} \\
(-2.320)\end{array}$ & $\begin{array}{l}-0.020 * * * \\
(-2.960)\end{array}$ & $\begin{array}{l}-0.019^{* * *} \\
(-2.673)\end{array}$ \\
\hline $\mathrm{CSR} \times \mathrm{ACCONLY}$ & $\begin{array}{c}0.003 \\
(0.205)\end{array}$ & & & & & & $\begin{array}{c}0.001 \\
(0.128)\end{array}$ \\
\hline $\mathrm{CSR} \times$ FINONLY & & $\begin{array}{l}-0.022 * * \\
(-2.395)\end{array}$ & & & & & $\begin{array}{l}-0.020 * \\
(-1.947)\end{array}$ \\
\hline $\mathrm{CSR} \times \mathrm{SUPONLY}$ & & & $\begin{array}{c}0.017 \\
(1.282)\end{array}$ & & & & $\begin{array}{l}0.013 \\
(0.614)\end{array}$ \\
\hline $\mathrm{CSR} \times \mathrm{ACCFIN}$ & & & & $\begin{array}{l}-0.044^{* * *} \\
(-3.992)\end{array}$ & & & $\begin{array}{l}-0.041 * \\
(-1.686)\end{array}$ \\
\hline $\mathrm{CSR} \times \mathrm{ACCSUP}$ & & & & & $\begin{array}{l}-0.024 \\
(-1.541)\end{array}$ & & $\begin{array}{l}-0.021 \\
(-1.053)\end{array}$ \\
\hline
\end{tabular}


Table 5. Cont.

\begin{tabular}{|c|c|c|c|c|c|c|c|}
\hline \multirow{2}{*}{ Variable } & \multicolumn{7}{|c|}{ Dependent Variable $=$ DA } \\
\hline & (1) & (2) & (3) & (4) & (5) & (6) & (7) \\
\hline CSR $\times$ FINSUP & & & & & & $\begin{array}{c}0.012 \\
(0.472)\end{array}$ & $\begin{array}{c}0.011 \\
(0.407)\end{array}$ \\
\hline $\mathrm{CSR} \times \mathrm{ALL}$ & & & & & & & $\begin{array}{c}0.088^{* * *} \\
(4.850)\end{array}$ \\
\hline ACCONLY & $\begin{array}{c}-0.003 \\
(-0.239)\end{array}$ & & & & & & $\begin{array}{c}-0.002 \\
(-0.332)\end{array}$ \\
\hline FINONLY & & $\begin{array}{l}-0.002 \\
(-0.120)\end{array}$ & & & & & $\begin{array}{l}-0.001 \\
(-0.076)\end{array}$ \\
\hline SUPONLY & & & $\begin{array}{c}-0.002 \\
(-0.270)\end{array}$ & & & & $\begin{array}{c}-0.002 \\
(-0.159)\end{array}$ \\
\hline ACCFIN & & & & $\begin{array}{c}0.060 * * \\
(2.152)\end{array}$ & & & $\begin{array}{l}0.056^{*} \\
(1.739)\end{array}$ \\
\hline ACCSUP & & & & & $\begin{array}{c}0.014^{* *} \\
(2.060)\end{array}$ & & $\begin{array}{c}0.012 \\
(0.867)\end{array}$ \\
\hline FINSUP & & & & & & $\begin{array}{c}-0.013 \\
(-0.830)\end{array}$ & $\begin{array}{c}-0.011 \\
(-0.491)\end{array}$ \\
\hline ALL & & & & & & & $\begin{array}{l}-0.069 * * \\
(-2.450)\end{array}$ \\
\hline ACIND & $\begin{array}{c}0.009 \\
(0.892)\end{array}$ & $\begin{array}{c}0.008 \\
(0.799)\end{array}$ & $\begin{array}{c}0.008 \\
(0.793)\end{array}$ & $\begin{array}{c}0.007 \\
(0.606)\end{array}$ & $\begin{array}{c}0.010 \\
(0.929)\end{array}$ & $\begin{array}{c}0.009 \\
(0.956)\end{array}$ & $\begin{array}{c}0.009 \\
(0.876)\end{array}$ \\
\hline lnACACTIVITY & $\begin{array}{c}-0.005 \\
(-1.090)\end{array}$ & $\begin{array}{c}-0.005 \\
(-1.165)\end{array}$ & $\begin{array}{c}-0.005 \\
(-1.205)\end{array}$ & $\begin{array}{c}-0.005 \\
(-1.044)\end{array}$ & $\begin{array}{c}-0.005 \\
(-1.141)\end{array}$ & $\begin{array}{c}-0.005 \\
(-1.016)\end{array}$ & $\begin{array}{c}-0.005 \\
(-1.098)\end{array}$ \\
\hline $\operatorname{lnACTENURE~}$ & $\begin{array}{c}0.003 \\
(0.625)\end{array}$ & $\begin{array}{c}0.002 \\
(0.593)\end{array}$ & $\begin{array}{c}0.003 \\
(0.705)\end{array}$ & $\begin{array}{c}0.003 \\
(0.709)\end{array}$ & $\begin{array}{c}0.003 \\
(0.700)\end{array}$ & $\begin{array}{c}0.002 \\
(0.618)\end{array}$ & $\begin{array}{c}0.003 \\
(0.709)\end{array}$ \\
\hline SIZE & $\begin{array}{l}-0.004 * \\
(-1.734)\end{array}$ & $\begin{array}{l}-0.004^{*} \\
(-1.860)\end{array}$ & $\begin{array}{l}-0.004 * \\
(-1.815)\end{array}$ & $\begin{array}{l}-0.004 * \\
(-1.912)\end{array}$ & $\begin{array}{l}-0.004 \\
(-1.924)\end{array}$ & $\begin{array}{l}-0.004 * \\
(-1.668)\end{array}$ & $\begin{array}{c}-0.004 * * * \\
(-2.776)\end{array}$ \\
\hline STDCFO & $\begin{array}{c}-0.120^{* * *} \\
(-3.511)\end{array}$ & $\begin{array}{c}-0.126^{* * *} \\
(-3.741)\end{array}$ & $\begin{array}{c}-0.116^{* * *} \\
(-3.758)\end{array}$ & $\begin{array}{c}-0.124^{* * *} \\
(-3.681)\end{array}$ & $\begin{array}{c}-0.127^{* * * *} \\
(-3.799)\end{array}$ & $\begin{array}{c}-0.119 * * * \\
(-4.564)\end{array}$ & $\begin{array}{c}-0.140 * * * \\
(-5.831)\end{array}$ \\
\hline ZSCORE & $\begin{array}{c}0.000 \\
(0.077)\end{array}$ & $\begin{array}{c}-0.000 \\
(-0.177)\end{array}$ & $\begin{array}{c}0.000 \\
(0.040)\end{array}$ & $\begin{array}{c}-0.000 \\
(-0.598)\end{array}$ & $\begin{array}{c}-0.000 \\
(-0.058)\end{array}$ & $\begin{array}{l}-0.000 \\
(-0.094)\end{array}$ & $\begin{array}{l}-0.000 \\
(-0.753)\end{array}$ \\
\hline LOSS & $\begin{array}{c}-0.006 \\
(-0.774)\end{array}$ & $\begin{array}{c}-0.006 \\
(-0.861)\end{array}$ & $\begin{array}{c}-0.005 \\
(-0.727)\end{array}$ & $\begin{array}{c}-0.006 \\
(-0.799)\end{array}$ & $\begin{array}{c}-0.005 \\
(-0.706)\end{array}$ & $\begin{array}{c}-0.005 \\
(-0.771)\end{array}$ & $\begin{array}{c}-0.007 \\
(-0.754)\end{array}$ \\
\hline TACCt-1 & $\begin{array}{l}0.102 * \\
(1.912)\end{array}$ & $\begin{array}{l}0.100 * \\
(1.775)\end{array}$ & $\begin{array}{l}0.102 * \\
(1.913)\end{array}$ & $\begin{array}{l}0.101 * \\
(1.804)\end{array}$ & $\begin{array}{c}0.107^{* *} \\
(2.113)\end{array}$ & $\begin{array}{c}0.100^{* *} \\
(1.981)\end{array}$ & $\begin{array}{l}0.105^{* *} \\
(2.227)\end{array}$ \\
\hline BIGAUDITOR & $\begin{array}{c}-0.004 \\
(-0.276)\end{array}$ & $\begin{array}{c}-0.005 \\
(-0.350)\end{array}$ & $\begin{array}{c}-0.003 \\
(-0.179)\end{array}$ & $\begin{array}{c}-0.003 \\
(-0.256)\end{array}$ & $\begin{array}{c}-0.004 \\
(-0.330)\end{array}$ & $\begin{array}{c}-0.004 \\
(-0.300)\end{array}$ & $\begin{array}{c}-0.004 \\
(-0.312)\end{array}$ \\
\hline AUDEXPERT & $\begin{array}{l}-0.014 \text { ** } \\
(-2.015)\end{array}$ & $\begin{array}{l}-0.014 * \\
(-1.950)\end{array}$ & $\begin{array}{l}-0.014 * * \\
(-2.039)\end{array}$ & $\begin{array}{l}-0.013 * \\
(-1.862)\end{array}$ & $\begin{array}{l}-0.015^{* *} \\
(-2.002)\end{array}$ & $\begin{array}{l}-0.014^{* *} \\
(-2.027)\end{array}$ & $\begin{array}{l}-0.013 * \\
(-1.839)\end{array}$ \\
\hline CLEAN & $\begin{array}{c}0.013 \\
(0.703)\end{array}$ & $\begin{array}{c}0.013 \\
(0.601)\end{array}$ & $\begin{array}{c}0.012 \\
(0.613)\end{array}$ & $\begin{array}{c}0.011 \\
(0.480)\end{array}$ & $\begin{array}{c}0.011 \\
(0.550)\end{array}$ & $\begin{array}{c}0.008 \\
(0.428)\end{array}$ & $\begin{array}{c}0.007 \\
(0.321)\end{array}$ \\
\hline $\ln A G E$ & $\begin{array}{l}-0.007^{* * * *} \\
(-2.992)\end{array}$ & $\begin{array}{l}-0.007^{* * *} \\
(-2.933)\end{array}$ & $\begin{array}{l}-0.007^{* * * *} \\
(-3.568)\end{array}$ & $\begin{array}{l}-0.006^{* *} \\
(-2.461)\end{array}$ & $\begin{array}{l}-0.007^{* * *} \\
(-3.299)\end{array}$ & $\begin{array}{l}-0.007^{* * * *} \\
(-3.066)\end{array}$ & $\begin{array}{l}-0.007^{* * *} \\
(-2.863)\end{array}$ \\
\hline $\begin{array}{l}\text { Industry/Year fixed } \\
\text { effects }\end{array}$ & Yes & Yes & Yes & Yes & Yes & Yes & Yes \\
\hline Clustering & Firm-years & Firm-years & Firm-years & Firm-years & Firm-years & Firm-years & Firm-years \\
\hline Observations & 896 & 896 & 896 & 896 & 896 & 896 & 896 \\
\hline Adjusted R2 & 0.043 & 0.045 & 0.044 & 0.052 & 0.045 & 0.044 & 0.053 \\
\hline
\end{tabular}

Note: The symbols $* * *$, and ${ }^{* * *}$ denote significance at $0.10,0.05$, and 0.01 levels, respectively (all two-tailed tests). The variables are presented in the Appendix A, Table A1.

\section{Conclusions}

This study verifies the role of AC financial expertise in the relationship between CSR and earnings quality. The Korean firms that practice CSR strictly manage their earnings ${ }^{\prime}$ quality. Moreover, when there is a certified accountant in their AC, these firms control earnings management more strictly through discretionary accruals. This is more effective when an AC has members with diverse expertise that includes accounting. The additional 
analysis finds that when an AC comprises only finance experts or both accounting and finance experts, the negative (-) correlation between CSR and discretionary accruals is further intensified. This result adds robustness to the main results and demonstrates that the effect of the ACs of the firms that practice CSR based on ethical motivation varies depending on the composition of the AC's financial expertise.

In the recent environment where a firm's environment, social, and governance performance is emphasized, CSR acts as an important strategy and element and is used to maintain corporate sustainability. This is the first study related to CSR that simultaneously considers AC accounting, finance, and supervisory expertise. While previous studies have examined the impact of AC financial expertise, including accounting, finance, and supervisory expertise on financial reporting, this study employs the subtypes of financial experts on ACs as the proxies for AC financial expertise. Specifically, it considers certified accountants, accounting professors, other accounting experts, finance professors, other finance experts, and supervisory experts, respectively and simultaneously. The results lead to a deeper understanding of the effectiveness of AC financial expertise, and its effect on the association between CSR and earnings quality.

The results of the study have useful implications for the various stakeholders of CSR practicing firms, such as regulatory agencies, investors, and auditors. Regulatory agencies that wish to improve corporate governance, such as through ACs, can utilize the study findings, which show that ACs play a positive role in improving the accounting information quality of firms with CSR excellence. The role of accounting experts in an AC is important for maintaining high earnings quality; moreover, combining various types of expertise creates synergy. These findings could be used to establish a regulation to improve ACs and better supervise the quality of financial reporting. The study results suggest that when making investment decisions, the investors should consider not only a firm's financial statements but also its CSR activities and the composition of its AC. Auditors must pay attention to the fact that the financial reporting quality of firms may vary depending on the level of CSR and characteristics of their ACs. Future research may extend the findings of this study and add to the literature by employing a variety of classifications of AC expertise, including non-financial expertise.

Author Contributions: Conceptualization, H.R. and B.S.; methodology, B.S. and S.-J.C.; formal analysis, B.S. and S.-J.C.; writing-original draft, H.R. and B.S.; writing-review and editing, H.R. and S.-J.C.; funding acquisition, H.R. All authors have read and agreed to the published version of the manuscript.

Funding: This work was supported by the Ministry of Education of the Republic of Korea and the National Research Foundation of Korea (NRF-2021S1A5A8070518).

Institutional Review Board Statement: Not applicable.

Informed Consent Statement: Not applicable.

Data Availability Statement: Not applicable.

Conflicts of Interest: The authors declare no conflict of interest.

Appendix A

Table A1. Variable definitions.

\begin{tabular}{cc}
\hline Variable & Definition \\
\hline DA & Performance-matched discretionary accruals [28] \\
\hline CSR & Dummy variable that equals to 1 if the firm is ranked in the KEJI Index and 0 otherwise \\
\hline ACCCERT & Dummy variable that equals to 1 if the firm's AC includes at least one certified accountant and 0 otherwise \\
\hline ACCPROF & Dummy variable that equals to 1 if the firm's AC employs at least one accounting expert who is neither a certified \\
accountant nor an accounting professor and 0 otherwise
\end{tabular}


Table A1. Cont.

\begin{tabular}{|c|c|}
\hline Variable & Definition \\
\hline FINPROF & Dummy variable that equals to 1 if the firm's AC includes at least one finance professor and 0 otherwise \\
\hline FINOTHERS & $\begin{array}{l}\text { Dummy variable that equals to } 1 \text { if the firm's } \mathrm{AC} \text { includes at least one finance expert excluding finance professors and } \\
0 \text { otherwise }\end{array}$ \\
\hline SUP & Dummy variable that equals to 1 if the firm's $\mathrm{AC}$ includes at least one supervisory expert and 0 otherwise \\
\hline ACCONLY & $\begin{array}{c}\text { Dummy variable that equals to } 1 \text { if the firm's AC includes at least one accounting expert but no finance or supervisory } \\
\text { experts and } 0 \text { otherwise }\end{array}$ \\
\hline ACCANDANOTHER & $\begin{array}{l}\text { Dummy variable that equals to } 1 \text { if the firm's AC includes at least one accounting expert and finance or supervisory } \\
\text { expert and } 0 \text { otherwise }\end{array}$ \\
\hline ALL & $\begin{array}{l}\text { Dummy variable that equals to } 1 \text { if the firm's AC includes at least one accounting expert, at least one finance expert, } \\
\text { and at least one supervisory expert and } 0 \text { otherwise }\end{array}$ \\
\hline FINONLY & $\begin{array}{l}\text { Dummy variable that equals to } 1 \text { if the firm's AC includes at least one finance expert but no accounting or supervisory } \\
\text { experts and } 0 \text { otherwise }\end{array}$ \\
\hline SUPONLY & $\begin{array}{c}\text { Dummy variable that equals to } 1 \text { if the firm's AC includes at least one supervisory expert but no accounting or finance } \\
\text { experts and } 0 \text { otherwise }\end{array}$ \\
\hline ACCFIN & $\begin{array}{l}\text { Dummy variable that equals to } 1 \text { if the firm's AC includes at least one accounting expert and at least one finance } \\
\text { expert but no supervisory expert and } 0 \text { otherwise }\end{array}$ \\
\hline ACCSUP & $\begin{array}{l}\text { Dummy variable that equals to } 1 \text { if the firm's AC includes at least one accounting expert and supervisory expert but } \\
\text { no finance expert and } 0 \text { otherwise }\end{array}$ \\
\hline FINSUP & $\begin{array}{l}\text { Dummy variable that equals to } 1 \text { if the firm's AC includes at least one finance expert and supervisory expert but no } \\
\text { accounting expert and } 0 \text { otherwise }\end{array}$ \\
\hline ACIND & Dummy variable that equals to 1 if all $\mathrm{AC}$ members are independent and 0 otherwise \\
\hline $\ln A C A C T I V I T Y$ & Natural logarithm of the number of AC meetings held during the fiscal year \\
\hline $\ln A C T E N U R E$ & Natural logarithm of the average number of years AC members have served as a firm's directors \\
\hline SIZE & Natural logarithm of total assets \\
\hline STDCFO & Past three-years' standard deviation of operating cash flows divided by lagged total assets \\
\hline ZSCORE & Financial risk measure [33] \\
\hline LOSS & Dummy variable that equals to 1 if a firm has a net loss during the fiscal year and 0 otherwise \\
\hline TACCt-1 & Total accruals (=net income - operating cash flows) divided by total the assets observed at the beginning of the year \\
\hline BIGAUDITOR & Dummy variable that equals to 1 if an auditor is one of the Big $N$ and 0 otherwise \\
\hline AUDEXPERT & $\begin{array}{c}\text { Dummy variable that equals to } 1 \text { if a firm's external auditor has the largest market share based on sales during an } \\
\text { industry-year and } 0 \text { otherwise }\end{array}$ \\
\hline CLEAN & Dummy variable that equals to 1 if the audit opinion is unqualified and 0 otherwise \\
\hline $\ln A G E$ & Natural logarithm of firm age \\
\hline
\end{tabular}

\section{References}

1. Brammer, S.; Brooks, C.; Pavelin, S. Corporate social performance and stock returns: UK evidence from disaggregate measures. Financ. Manag. 2006, 35, 97-116. [CrossRef]

2. Kim, Y.T.; Park, M.S.; Wier, B. Is earnings quality associated with corporate social responsibility? Acc. Rev. 2012, 87, 761-796. [CrossRef]

3. Choi, H.J.; Moon, D.C. The relationship between corporate social responsibilities and accounting transparency. Korean Acc. Rev. 2013, 38, 135-171. (In Korean)

4. Securities and Exchange Commission (SEC). Accounting and Auditing Enforcement Release; SEC: Washington, DC, USA, 2003; Volume 1839.

5. Kwak, S.-K. A critical review on the literature about the audit committee. J. Tax. Acc. 2010, 11, 175-217. (In Korean)

6. Song, B.; Ahn, H.; Choi, J.-H. The effect of the composition of audit committee financial expertise on industry specialist auditor choice and audit. Korean Acc. Rev. 2017, 42, 209-243. [CrossRef]

7. Lee, S.C.; Lee, K.T. An empirical study on the effect of an audit committee on earnings management. Korean Acc. Rev. 2003, 28, 143-172. (In Korean)

8. Jeon, K.-A.; Choi, J.-H.; Park, J.-I. The relationship between new audit committee establishment and earnings management. Korean Acc. Rev. 2004, 29, 143-177. (In Korean)

9. Prior, D.; Surroca, J.; Tribó, J.A. Are socially responsible managers really ethical? Exploring the relationship between earnings management and corporate social responsibility. Corp. Gov. Int. Rev. 2008, 16, 160-177. [CrossRef]

10. Muttakin, M.B.; Khan, A.; Azim, M.I. Corporate social responsibility disclosures and earnings quality. Manag. Aud. J. 2015, 30, 277-298. [CrossRef] 
11. Salewski, M.; Zulch, H. The Impact of Corporate Social Responsibility (CSR) on Financial Reporting Quality-Evidence from European Blue Chips; Working Paper; HHL_Leipzig Graduate School of Management: Saxony, Germany, 2014.

12. Moon, H.J. The relationship between ethical management and discretionary accruals. Korean Acc. J. 2007, 16, 81-105. (In Korean)

13. Lim, H.J.; Cho, J.S. Corporate social responsibility and earnings management: Do the external business ethics portray internal ethics? Korean Acc. J. 2013, 22, 257-309. (In Korean)

14. Kim, S.H.; Jung, Y.K. The monitoring power of foreign ownership on corporate social responsibility: Evidence from Korea. Korean Acc. Rev. 2012, 37, 1-62. (In Korean)

15. Kim, Y.H. The effect of CSR on earnings management and firm value. Tax. Acc. Res. 2014, 40, 147-163. (In Korean)

16. Ban, H.J. Corporate governance structure, corporate social responsibility, and its performance. J. Ind. Econ. Bus. 2009, 22, 2171-2195. (In Korean)

17. Jung, W.S. The effects of corporate social responsibility on the tax strategy and firm value to the tax strategy—Focus on corporate governance. Korea Intl. Acc. Rev. 2015, 60, 181-206. (In Korean) [CrossRef]

18. Hwang, S.J.; Ryu, S.J. The effect of corporate governance on the relationship between CEO compensation and CSR. Tax Acc. Res. 2020, 64, 27-52. (In Korean) [CrossRef]

19. Shaukat, A.; Qiu, Y.; Trojanowski, G. Board attributes, corporate social responsibility strategy, and corporate environmental and social performance. J. Bus. Ethics 2016, 135, 569-585. [CrossRef]

20. Xie, B.; Davidson, W.N., III; DaDalt, P.J. Earnings management and corporate governance: The role of the board and the audit committee. J. Corp. Fin. 2003, 9, 295-316. [CrossRef]

21. Bédard, J.; Chtourou, S.M.; Courteau, L. The effect of audit committee expertise, independence, and activity on aggressive earnings management. Aud. J. Pract. Theor. 2004, 23, 13-35. [CrossRef]

22. Keune, M.B.; Johnstone, K.M. Materiality judgments and the resolution of detected misstatements: The role of managers, auditors, and audit committees. Acc. Rev. 2012, 87, 1641-1677. [CrossRef]

23. Zhang, Y.; Zhou, J.; Zhou, N. Audit committee quality, auditor independence, and internal control weaknesses. J. Acc. Public Policy 2007, 26, 300-327. [CrossRef]

24. Krishnan, G.V.; Visvanathan, G. Does the SOX definition of an accounting expert matter? The association between audit committee directors' accounting expertise and accounting conservatism. Contemp. Acc. Res. 2008, 25, 827-858. [CrossRef]

25. Schmidt, J.; Wilkins, M.S. Bringing darkness to light: The influence of auditor quality and audit committee expertise on the timeliness of financial statement restatement disclosures. Aud. J. Pract. Theor. 2013, 32, 221-244. [CrossRef]

26. Cohen, J.R.; Hoitash, U.; Krishnamoorthy, G.; Wright, A.M. The effect of audit committee industry expertise on monitoring the financial reporting process. Acc. Rev. 2014, 89, 243-273. [CrossRef]

27. Dhaliwal, D.; Naiker, V.; Navissi, F. The association between accruals quality and the characteristics of accounting experts and mix of expertise on audit committees. Contemp. Acc. Res. 2010, 27, 787-827. [CrossRef]

28. Kothari, S.P.; Leone, A.J.; Wasley, C.E. Performance matched discretionary accrual measures. J. Acc. Econ. 2005, 39, 163-197. [CrossRef]

29. Becker, C.L.; DeFond, M.L.; Jiambalvo, J.; Subramanyam, K.R. The effect of audit quality on earnings management. Contemp. Acc. Res. 1998, 15, 1-24. [CrossRef]

30. Hribar, P.; Craig Nichols, D.C. The use of unsigned earnings quality measures in tests of earnings management. J. Acc. Res. 2007, 45, 1017-1053. [CrossRef]

31. Petersen, M.A. Estimating standard errors in finance panel data sets: Comparing approaches. Rev. Financ. Stud. 2009, 22, 435-480. [CrossRef]

32. Gow, I.D.; Ormazabal, G.; Taylor, D.J. Correcting for cross-sectional and time-series dependence in accounting research. Acc. Rev. 2010, 85, 483-512. [CrossRef]

33. Altman, E.I. Financial ratios, discriminant analysis and the prediction of corporate bankruptcy. J. Fin. 1968, 23, 589-609. [CrossRef] 